\title{
P. Aghion, C. Antonin, S. Bunel, The power of creative destruction: Economic upheaval and the wealth of nations
}

\author{
400 pp., Belkap Press, Cambridge (Mass.), 2021, $31.50 €$
}

\author{
Alberto Bucci ${ }^{1,2,3,4}$ \\ Published online: 24 January 2022 \\ (C) The Author(s), under exclusive licence to Springer-Verlag GmbH Austria, part of Springer Nature 2021
}

JEL Classification B22 $\cdot$ E02 $\cdot \mathrm{N} 1 \cdot \mathrm{O} 3 \cdot \mathrm{O} 4$

The latest crises (the financial crisis of 2007/2008 and the more recent COVID-19 epidemic) have revitalized a long-lasting debate among economists: How should our target-economy look like? Which levers can a policy-maker use to reach the targeted economy? Can innovation be one of these levers? If yes, how can innovation be a major engine of long-term economic growth without, at the same time, exacerbating social inequality? What are the main implications of innovation for globalization, employment, health and human happiness? What is the role that a "State" can play in all this? In a word: What is the future of capitalism, and how can we ultimately re-shape it?

These are the crucial questions that Aghion, Antonin and Bunel (A-A-B, hereafter) try to answer in their impressive book that encompasses more than thirty years of active research in the fields of economic theory and innovation-driven growth. Answering these questions requires the use of a fundamental paradigm (or framework of analysis), and the one that A-A-B decide to employ is the Schumpeter's 'Creative Destruction' model. The reason for this is easy to understand as long as one remembers that according to Schumpeter (1942, Chapter VII):

Alberto Bucci

alberto.bucci@unimi.it

1 University of Milan, Milan, Italy

2 ICEA - International Centre for Economic Analysis, Wilfrid Laurier University, Ontario, Waterloo, Canada

3 CEIS - Centre for Economic and International Studies, University of Rome 'Tor-Vergata', Via Columbia, 2 - 00133 Rome, Italy

4 FinGro Lab - Research Laboratory on Finance and Growth, University of Milan, Via Conservatorio, 7, 20122 Milan, Italy 
"...The history of the productive apparatus of a typical farm...is a history of revolutions... The opening up of new markets, foreign or domestic, and the organizational development from the craft shop and factory to such concerns as U.S. steel illustrate the same process of industrial mutation...that incessantly revolutionizes the economic structure from within, incessantly destroying the old one, incessantly creating a new one. This process of Creative Destruction is the essential fact about capitalism. It is what capitalism consists in and what every capitalist concern has got to live in. This fact bears upon our problem in two ways... The first thing to go is the traditional conception of the modus operandi of competition. Economists are at long last emerging from the stage in which price competition was all they saw. As soon as quality competition and sales effort are admitted into the sacred precincts of theory, the price variable is ousted from its dominant position. However, it is still competition within a rigid pattern of invariant conditions, methods of production and forms of industrial organization in particular, that practically monopolizes attention. But in capitalist reality as distinguished from its textbook picture, it is not that kind of competition which counts but the competition from the new commodity, the new technology, the new source of supply, the new type of organization... - competition which commands a decisive cost or quality advantage and which strikes not at the margins of the profits and the outputs of the existing firms but at their foundations and their very lives. This kind of competition is as much more effective than the other as a bombardment is in comparison with forcing a door...."

Thus, according to Schumpeter, 'Creative Destruction' is the process by which: New innovations continuously arrive and cause existing products and technologies to become obsolete; New firms continuously emerge and start competing in the market-place with existing firms, destroying their rents; New jobs and activities continuously arise and replace older ones. This process "revolutionizes" all aspects of an economic system, and does represent the driving force of modern capitalism, simultaneously bringing prosperity (through the creative force of innovation) but also opposition and stagnation (through the disruptive force of the destruction that it naturally commands). This is the main reason why the process of creative destruction needs to be opportunely regulated and guided and, more importantly, this also explains why this paradigm does probably represent the most powerful tool to uncover and explore the (too!) many tradeoffs that still characterize modern economies.

The paradigm of creative destruction is based on three pillars: (1) Every innovation is built upon the knowledge embodied in previous innovations (i.e., every innovator 'stands on the shoulders of giants' that preceded her); (2) Given its cumulative nature, innovation needs a favorable institutional environment (for example, in the form of a strong system of economic incentives and a forceful protection of property rights) to be properly codified and diffused; (3) Innovation requires a competitive environment, as well, so that new innovative firms can 
unceasingly enter the market and compete with the incumbents without impediments.

These three basic ideas on which the Schumpeter's creative-destructionparadigm is founded are also those that allow A-A-B to explore in great detail the major enigmas of modern capitalism. The whole book is hence devoted to a comprehensive examination, through the Schumpeterian teachings' lens, of these major enigmas.

It contains fifteen chapters. Two common marks characterize them: (1) They offer an up-to-date list of references representing the state-of-the-art of the literature (theoretical/empirical) being thoroughly discussed; (2) The main message of the analysis is always presented intuitively, either through the discussion of simple correlations among economic variables, or through their causal interpretation. In other words, the book is written in a truly reader-friendly manner (and without the unnecessary burden of technicalities that often characterizes modern economic growth theory). This last feature makes the book an indispensable tool not only for practitioners and researchers actively working on innovation, economic growth and development, but also (and especially, I would say!) for policy- and decisionmakers, as well as students (at the master/PhD level) looking for an interesting topic of research for their graduate dissertation.

Chapter 1 is introductory, as it describes the Schumpeterian paradigm and shows why and how it can still be useful in understanding and explaining the central puzzles of modern economic systems.

Chapter 2 deals with the first of such puzzles (the economic take-off that started in 1820, first in the UK, then in France). In these two countries, the average annual rate of growth of per capita GDP jumped from a little $0.05 \%$ (before 1820) to $0.5 \%$ (from 1820 to 1870). After that time economic growth continued to accelerate, reaching approximately 3\% between 1950 and 1973 . What was the main engine of this economic take-off, and why did it take place in Western Europe and not elsewhere? The neoclassical model is silent on both questions, especially the first one, as in the neoclassical paradigm, due to the presence of decreasing returns to capital, economic growth tends to decline with capital accumulation. Instead, the Schumpeterian paradigm of creative destruction is able to provide an excellent explanation for this take-off, its timing and space. This explanation is based on the fact that at the time of the economic take-off it was definitely easier in Western Europe (particularly in countries such as the UK and France) to diffuse the knowledge being created by means of a well-organized postal service; moreover, among Western European nations there existed great competition for the most brilliant minds; finally, those nations had already introduced efficient institutions that protected intellectual property rights, so completing the institutional framework needed for an economic take-off to happen.

Likewise, the Schumpeterian paradigm is also able to shed light on another enigma (the so-called 'middle-income-trap', see Chapter 7 ), ${ }^{1}$ as well as on the

\footnotetext{
1 The 'middle-income-trap-enigma' is also known as the 'Argentinian-paradox'. Indeed, in 1890 Argentina enjoyed a per capita GDP approximately equal to $40 \%$ that of the US, a level being, at the time, even slightly higher than France's per capita GDP. However, after 1938 Argentina's per capita GDP started to decline very quickly relative to US per capita GDP. According to the Schumpeterian paradigm,
} 
possible causes behind the de-industrialization and the transition to a 'serviceseconomy' (see Chapter 8$)^{2}$

The direct and indirect effects of automation (i.e., the third industrial revolution, or the $\mathrm{IT}^{3}$-revolution) on employment and growth (both at the aggregate- and the firm- level) are studied more thoroughly in Chapter 3. The analysis convincingly shows that: (a) Technological revolutions (including the third one) are generally associated with an acceleration of economic growth, although with some delays (whose length is proportional to the degree of inappropriateness of the extant institutions); (b) Such revolutions are not necessarily detrimental to employment, as firms that automate their production usually end up being net job-creators.

Chapter 4 is probably one of the central chapters of the book. It deals with another fundamental enigma: Why, in theory, anything that weakens innovation rents (including increased product market competition) has a detrimental impact on innovation and growth, while, in practice, empirical studies using firm-level data show a positive correlation between the intensity of sectorial competition and the rate of productivity growth in the same sector? The neoclassical paradigm has nothing to say on this enigma, as it assumes perfect competition in all markets. Hence, according to $\mathrm{A}-\mathrm{A}-\mathrm{B}$, the key to solve this puzzle resides solely in the creative destruction paradigm and, in more detail, in the need to distinguish between two different types of firms: those being close to their sector's technological frontier (the innovation effort of these firms definitely increases with rivalry, in order to 'escape' tougher product-market-competition), from those being far from their technological frontier (the innovation effort of these firms falls with increased competition). The composition of these two effects implies that the overall impact of competition on innovation is inverted-U-shaped, which suffices to reconcile the initial Schumpeterian's view with existing empirical evidence. ${ }^{4}$

\section{Footnote 1 continued}

the main reason for this was the failure of Argentina to adopt institutions capable of driving the transition from a purely agricultural economy (based on factor-accumulation) to an industrial one (based on innovation).

2 Indeed, among the possible theories that can explain the de-industrialization and the transition to 'services' of modern economies, there is one particularly fascinating which is dictated directly by the Schumpeterian view. The story goes as follows. Due to the higher automatization that over time has been occurring in the production of goods, the growth in labor productivity is stronger in manufacturing and agriculture than in the services-sector. The general increase in labor productivity (owing to the continuing substitution of capital for labor) frees up workers in agriculture and manufacturing and pushes wages downwards. The decline in labor-costs in the goods-sectors increases the rents from introducing new services (actually, production of services relies more on labor, so a decline in wages increases the profitability of creating new services). This, in turn, has two implications: first, the services-sector expands over time (accelerating the transition from a production- to a services-economy); secondly, the expansion of the services-sector increases the demand for labor. This increase pushes wages upwards again, so restoring the initial share of labor in income (that, thus, can remain rather stable over the longterm, as predicted by the Kaldor's facts).

3 IT stands for Information Technology.

${ }^{4}$ See Aghion et al. (2005), Aghion et al. (2006), Aghion et al. (2009), who extend the basic Schumpeterian creative destruction model with the assumption that also incumbent firms (and not only new entrants) can innovate. However, as it is fairly said throughout the whole book, economic theory recognizes that there are also other paradigms (different from the Schumpeterian's one) able to explain some major enigmas that characterize most of developed economies. With regard to the relationship 
The paradigm of creative destruction predicts that every innovation enables the innovator to increase her profits, hence her income. As a result, innovation should lead to increased inequality at the top of the income-distribution. While this is certainly true in the short run, in the long term, however, innovation (especially when it comes from new entrants) creates also social mobility. The fact that innovation increases inequality at the top and at the same time it also spurs social mobility leads to the conclusion (discussed in Chapter 5) that, on the whole, the relation between innovation and inequality is ambiguous. This explains why, in this trade-off, taxation constitutes the fundamental tool to be used by a policy-maker in order to simultaneously stimulate economic growth, make it more inclusive (e.g., by investing the proceeds of taxes in growth-levers such as public education and health, research and infrastructures), while concurrently insuring individuals against the possible idiosyncratic risks of innovation (such as job-loss and skill-obsolescence).

Chapter 6 analyzes the puzzle of the so-called 'secular stagnation' (US growth has been declining since 2005, despite the IT- and $\mathrm{AI}^{5}$ - revolutions). Again the neoclassical paradigm has nothing to say on this issue, as it predicts a continuous decline in economic growth due to diminishing returns from capital accumulation. On the other hand, the Schumpeterian paradigm is more optimistic about the future for two possible reasons: these revolutions improve (also) the technology for generating and diffusing new ideas; moreover, combined with the higher degree of globalization of international trade, they contribute to increase the potential rewards from innovation (scale effects). In the light of all this, the theory put forward by AA-B to explain the US slowdown over the past two decades is based on the belief (borrowed from Gilbert, 2020) that those firms that become innovative leaders (or 'superstars') owing to the new technological waves (and that acquire over time a greater weight in the US economy) tend also to discourage innovation and research by new competing innovative firms in the same industrial arena. The main policy implication of this explanation of the slowdown is that, as long as competition policy does not take innovation into full account, the new technological revolutions are destined to hinder (rather than stimulate) $R \& D$ efforts and then economic growth.

Recently, another phenomenon that has reinforced the conviction that economic stagnation is unavoidable is the phenomenon of 'global warming' due to greenhouse gas emissions. In this regard, the creative destruction paradigm has much to say since it not only allows explaining why a new technology can replace an older one, but also accounts for a radical change in the way goods and services are produced (a notable example is the shift from the combustion to the electric engine). So, Chapter 9 analyzes the possible policy instruments (carbon-taxes, subsidies for greener innovations, technology transfers in favor of developing countries, or carbon tariffs, among many others) that can lead profit-seeking firms to re-direct

Footnote 4 continued

between competition and growth, for example, Bucci (2013) and Bucci et al. (2021) provide an alternative view on how to reconcile theoretical predictions with existing empirical conclusions.

5 AI stands for Artificial Intelligence. 
their innovation efforts towards cleaner technologies, given that a laissez-faire economy is unlikely to reach this objective. ${ }^{6}$

Chapters 10-12 are devoted more specifically to the role of public policies within a Schumpeterian economy. ${ }^{7}$ Indeed, unlike a purely-neoclassical economy, in a Schumpeterian framework the policy-maker has a wider array of instruments/ policies to be used to promote economic well-being (think, as possible examples, of the competition- and innovation funding- policies; the policies that increase the complementarity between innovation and education ${ }^{8}$; those that push towards more structural reforms of the labor markets, and that cover individuals and workers from the risk of losing their job following the destruction of existing firms and activities ${ }^{9}$; the policies protecting intellectual property rights).

Chapter 13 deepens our understanding of the relations among globalization, innovation, international trade and migration. It is estimated that, following the China's admission to the WTO (the so-called 'Chinese-shock'), the increase in the US-China trade between 1990 and 2007 caused a loss of 1,5 million American manufacturing jobs, a rough $21 \%$ of total manufacturing jobs lost in the United States in the same period. Adults with higher levels of education were particularly affected by this shock. What caused all this and, especially, what could a policymaker have done to alleviate the problem? The natural explanation for the huge loss of American jobs occurred in the wake of the recent increase in globalization is that higher competition from China (where labor is definitely cheaper) reduced drastically the profit-margins of American firms, so hampering first their ability to innovate and, ultimately, pushing them to shut down and fire workers. However, the 'Creative Destruction' paradigm suggests that firms are not all equal: according to this paradigm (Chapter 4), an increase in competition should lead firms close to the technological frontier to innovate more (in order to escape the greater degree of competition) and firms far from the technological frontier to innovate less. The conclusion is therefore that the consequences (on innovation-incentives, profitmargins, employment, and survival probability) of the so-called 'Chinese-shock' are not all equal: they are negative for firms far from the technological frontier and positive for firms close to the frontier. This is exactly what the empirical evidence seems to suggest (p. 256). So, a Schumpeterian policy-maker would never react to the Chinese-shock by mechanically increasing tariffs or import duties (as it has recently been done most often), but rather would respond by encouraging (through R\&D-subsidies) investments in innovation, in the knowledge economy and in

\footnotetext{
6 As a matter of fact, a firm that has already gained a competitive advantage in a polluting production or in the implementation of a polluting technology will continue to stick over time to the same polluting production/technology.

7 In this setting, public intervention is dictated by the fact that the single individual will tend to underinvest, both in innovation and embodied knowledge, because she does not fully internalize the benefits to the whole society coming from her investment in these two fundamental sources of sustainable growth.

${ }^{8}$ For example, this can happen through public R\&D-subsidies coupled with a stronger public investment in education.

9 “...Schumpeterian creative destruction is not only creative but also destructive. It eliminates jobs that used to exist...throwing workers into an increasingly hostile labor market and with an inadequate safety net..." (Case and Deaton, 2020).
} 
infrastructures, and by re-allocating resources and jobs (through the complementary use of industrial policy, see pp. 277-279) from less productive to more productive firms. The same policy-lesson applies to the relation between innovation and migration. Empirical evidence (p. 268) suggests, in fact, that migrated foreign-born individuals substantially contribute to the US innovation rate. As a consequence, the Schumpeterian migration-policy would consist not in raising walls and barriers, but rather in promoting integration and skill-acquisition by non-natives.

The last two chapters (14 and 15) discuss the double role that the 'State' should play in encouraging creative destruction in an innovation-led economy/society. The first (the 'State as investor') consists in preserving competition, easing the free-entry of new innovators into the markets for goods and services, and accelerating investments in human capital and R\&D by individuals and firms. The second (the 'State as insurer'), instead, consists in building an adequate social safety-net that allows to ensure workers against the risk of losing their jobs. Among possible others (discussed in the book), one important force able to induce the 'State' to play correctly both roles of 'investor' and 'insurer' is the responsiveness of civil society.

So, in the end of the analysis, what about the future of capitalism? The answer that A-A-B give to this question is rather optimistic. Unlike Schumpeter (1942), who believed that large corporations would at last push small and medium-sized firms out of the market, leading to the complete demise of the 'entrepreneur' and, hence, to the death of capitalism, the thesis put forward by $\mathrm{A}-\mathrm{A}-\mathrm{B}$ is that capitalism, if adequately guided and regulated, can still represent a powerful means to attain an equitable and sustainable economic and social progress.

Beyond this optimistic (and probably shareable) conclusion, I think there are three main reasons why one can appreciate this book: (1) It draws on cutting-edge theory and evidence, so it is extremely rigorous; (2) It paves the way to a regulated capitalism, and brilliantly shows the indispensable 'checks and balances' to be implemented for capitalism to concretely continue fostering economic growth, social cohesion, technological change and better life-conditions, all at once; (3) It is competently policy-oriented, in the sense that the formalisms of modern economic theory are replaced by a critical and provocative reflection on the new underpinnings over which we wish to build the next "wealth of nations". For all these reasons, I am truly convinced that this book may represent an authoritative reference for both positive and normative analyses on our economic future.

\section{References}

Aghion P, Bloom N, Blundell R, Griffith R, Howitt P (2005) Competition and innovation: an inverted-U relationship. Quart J Econ 120(2):701-728

Aghion P, Griffith R, Howitt P (2006) Vertical integration and competition. Am Econ Rev 96(2):97-102

Aghion P, Blundell R, Griffith R, Howitt P, Prantl S (2009) The effects of entry on incumbent innovation and productivity. Rev Econ Stat 91(1):20-32

Bucci A (2013) Returns to specialization, competition, population, and growth. J Econ Dyn Control 37(10):2023-2040

Bucci A, Carbonari L, Trovato G (2021) Variety, competition, and population in economic growth: theory and empirics. Macroecon Dyn 25(5):1303-1330 
Case A, Deaton A (2020) Deaths of despair and the future of capitalism. Princeton University Press, Princeton

Gilbert R (2020) Innovation matters: competition policy for the high-technology economy. MIT Press, Cambridge, MA

Schumpeter JA (1942) Capitalism, Socialism and Democracy. Harper Perennial, New York

Publisher's Note Springer Nature remains neutral with regard to jurisdictional claims in published maps and institutional affiliations. 